\title{
Article Title: Tradable instruments to fight climate change: a disappointing outcome
}

\section{Article Type:}
C OPINION
O PRIMER
C OVERVIEW
ADVANCED REVIEW
FOCUS ARTICLE
O SOFTWARE FOCUS

\section{Authors:}

\author{
First author name \\ Philippe Quirion, quirion@centre-cired.fr, ORCID iD: 0000-0003-4066-2984, CIRED- \\ CNRS, no conflict of interest
}

\begin{abstract}
Various tradable instruments have been implemented for climate change mitigation: emission trading systems, tradable energy-efficiency obligations, and tradable renewable energy quotas. Their track record has been disappointing so far: almost every emission trading has suffered from over-allocation which has undermined its effectiveness; tradable energy-efficiency obligations seem to have mostly co-financed investments that would have taken place anyway; tradable renewable energy quotas suffer from several shortcomings compared to alternative support systems, i.e., feed-in tariffs and premiums. I discuss the reasons for these failures (especially too superficial a reading of the work of researchers by policy makers) and ways to improve the situation (including encouraging systematic syntheses of academic work).
\end{abstract}




\section{INTRODUCTION}

Dozens of policies officially aimed at reducing greenhouse gas emissions are in place in every OECD country (OECD, 2020). Many of them belong to the so-called 'economic instruments' (Postic and Fettet, 2020): taxes on greenhouse gas emissions (which fall outside the scope of this article) and 'tradable instruments' (Cf. Box 1 for definitions). The situation is quite different for other environmental problems such as local air pollution or the protection of biodiversity, for which most countries have made greater use of prohibitions and emission or technology standards.

The argument in favour of tradable instruments goes back at least to Dales (1968) and Crocker (1966), and can be stated as follows. In general, polluters know the cost of reducing their own emissions better than public authorities, so that, starting from a situation where the latter set a given quantity of emissions for each polluter, letting polluters negotiate to reallocate these limits among themselves reduces costs without changing aggregate emissions and therefore, for a well-mixed pollutant such as atmospheric $\mathrm{CO}_{2}$, without impact on the environment.

The development of tradable instruments can be interpreted as an 'economisation' of environmental policies, both in terms of 'economy' (the production, distribution, and consumption of goods and services) and of 'economics' (the social science that studies the economy). Concerning economy, economisation has taken the form of the creation of markets, resulting from the combination of a quantitative objective (cap) and flexibility (trade). Concerning economics, it has taken the form of using economics to justify tradable instruments, whereas for regulations, other disciplines (mainly natural and engineering sciences) have had a much more important role.

Has this increasing use of tradable instruments made it possible to reduce costs without weakening the effectiveness of environmental policies, as their promoters have claimed? I review here the applications of tradable instruments in three areas, all aimed at reducing greenhouse gas emissions, directly or indirectly (by saving energy or developing renewable energies). These three cases, dealt with in turn, are emission trading systems (ETS); tradable energy-efficiency obligations; and tradable renewable energy quotas. I therefore leave aside other applications of tradable instruments, which are also widely used in the areas of air pollution, water and fish catching, and even in offsetting biodiversity damage (Smessaert et al., 2020). Finally, I discuss whether other public policies applied to climate change mitigation have a better record. 


\section{Box 1. Definition of a 'tradable instrument'}

I use the term 'tradable instrument' in the sense of a public measure or policy that:

- sets a maximum or minimum quantity (of polluting emissions, of extraction of a natural resource, of electricity from renewable sources, of energy savings, etc.) expressed in physical units;

- allows flexibility between economic agents as to how compliance with this limit is distributed;

- and allows market exchanges to set the price of a legal object (usually called a tradable allowance, certificate or permit) whose ownership is necessary to comply with this tradable instrument.

This definition excludes 'price instruments' (taxes, subsidies and deposit-refund systems), since they do not comply with the first criterion above. The expressions 'economic instruments' and 'marketbased instruments' are generally used in a broader sense, which includes both tradable instruments and price instruments.

However I include among the 'tradable instruments' the so-called 'indexed', 'relative' or 'intensity' policies, i.e. those that limit the ratio between the quantity that the public authorities seek to influence (e.g., polluting emissions) and an economic quantity, generally the production of a good or service, or an aggregate of these. Examples include policies that set a share of renewable energy in the electricity sold (called Renewable Portfolio Standards in the United States) or that limit $\mathrm{CO}_{2}$ emissions per tonne of steel, per MWh of electricity generated or per unit of GDP (Newell and Pizer, 2008; Quirion, 2005).

\section{EMISSION TRADING SYSTEMS FOR GREENHOUSE GAS EMISSIONS}

Applied in the United States to reduce air pollution in the 1990s, these systems have developed in many countries to limit greenhouse gas emissions: the United Kingdom, the European Union, South Korea, New Zealand, and several cities, provinces and states in Canada, the United States, China and Japan (Postic and Fettet, 2020). A public authority allocates or sells a limited number of tradable allowances, which must be given back in amount equal to emissions.

While it is of course difficult to summarise the results of all these systems in a few lines, they have at least one thing in common: everywhere except in South Korea there has been an over-allocation of 
allowances, in the sense that the quantity of emissions allowed has exceeded the level of emissions that would have occurred in the absence of these systems, at least for a period of time ${ }^{1}$ (Box 2). There are various reasons for this over-allocation (Buchner and Ellerman, 2006; Borenstein et al., 2019; Burtraw and Keyes, 2018). First, a lack of knowledge about the emissions covered, due in particular to the asymmetry of information between the government and the firms, when the emission cap is determined (e.g., Modelina et al., 2003). Second, other policies reduce emissions from installations covered by the tradable instrument, sometimes to a greater extent than anticipated. For example, emissions from the power sector are declining as a result of support for renewables, energy conservation, and air quality policies that reduce the use of coal-fired power plants. Third, external credits ('offsets'), such as those from the Kyoto Protocol's Clean Development Mechanism, have sometimes become more important than anticipated. Last, surprises occur on the economic situation and energy prices, which influence emissions. In particular, the 2008-2009 crisis has massively reduced activity in the building and public works sector, thus reducing the demand for allowances by industries producing construction materials. Similarly, the massive production of shale gas in the United States has sharply reduced the activity of coal-fired power plants and thus $\mathrm{CO}_{2}$ emissions of the electricity sector, making the RGGI system's emissions cap non-binding (Box 2).

The paradox here is that over-allocation has occurred because of unforeseen events (in other words: because of uncertainty), whereas, as we have seen, it is precisely the uncertainty suffered by the public authorities (as to the costs of reducing emissions) which is the basis for the supposed superiority of tradable instruments over emission or technology standards! In fact, the research that underpins this supposed superiority, in particular the work of Dales (1968) and Montgomery (1972), is based on a given aggregate level of pollution, but does not take into account the fact that the choice of the optimal pollution level itself depends on uncertainty.

Since then, the reaction of tradable instruments to uncertainty has been the subject of much academic work, starting with Weitzman's (1974) seminal article which examines the conditions under which a 'price instrument' (a tax or subsidy) is preferable to a 'quantity instrument' such as an ETS. All the work that has applied this framework to greenhouse gas emissions since Pizer (1999) has

\footnotetext{
${ }^{1}$ South Korea is an exception so far (Park and Lee, 2020), but its ETS started only in 2015, and how it will perform following the Covid-19 global crisis remains to be seen.
} 
concluded that a tax is preferable to a tradable instrument, or that, in the case of a tradable instrument, it is desirable to set a floor price for allowances, thus creating a hybrid of price and quantity instruments (Branger et al., 2015). This is indeed the case in California, where a floor price exists and largely determines the value of allowances (Borenstein et al., 2019). For the time being, therefore, the California system functions more like a price instrument (a carbon tax) than a quantity instrument (an ETS).

However, in the largest emission trading system currently functioning, the EU ETS (Bailey, 2010; Laing et al., 2014), the European Commission and the Member States have thus far refused to introduce a floor price. The reasons for this refusal are not very clear. Ideological arguments are sometimes put forward: the market should be allowed to set the price freely, without state intervention - yet it is state intervention that has created the emission allowance market in the first place. Sometimes a legal argument is also put forward. The argument, which is contested among legal experts (Flachsland et al., 2019), is that a floor price would bring the system closer to a tax, hence the risk that the related directives would be considered as taxation, involving decisions taken unanimously by Member States and not by qualified majority.

In any case, the reform recently adopted in Europe has taken the extremely complex form of a 'price stability reserve' (Perino, 2018) whose capacity to stabilise prices is questioned by most of the research work it has generated (Fuss et al., 2018).

Box 2. Empirical evidence on over-allocation of allowances

- $\quad$ In the UK Emission Trading System (ETS), which remained in place from 2002 to 2006, overallocation was massive (Smith and Swierzbinski, 2007).

- $\quad$ In the Regional Greenhouse Gas Initiative (RGGI, Narassimhan et al., 2018), which has been covering $\mathrm{CO}_{2}$ emissions from power plants in the north-eastern US states since 2008, emissions during Phase 1 (2009-2011) were 33\% below the cap, a discrepancy that cannot be explained by abatement given the very modest allowance price (around $\$ 2$ per tonne of $\mathrm{CO}_{2}$ ).

- $\quad$ The first phase (2005-2007) of the European Union Emission Trading System (EU ETS) can be analysed separately from the following phases (since 2008), because the allowances from phase 1 could not be used in the next periods. During this first phase, emissions were about $3 \%$ below allocations according to Buchner and Ellerman (2006), who conclude that part of this surplus is due to 
the emission reduction driven by the carbon price, but that an over-allocation did indeed take place (i.e. the cap was higher than the emissions that would have occurred without the ETS).

- $\quad$ In the second phase of the EU ETS (2008-2012), the emissions cap was binding in 2008 but the 2009 crisis led to a massive reduction in emissions. As a result, an over-allocation occurred again. The price did not fall to zero only because allowances can be carried over to the next periods.

There is increasing evidence of over-allocation in most of the Chinese pilot ETSs implemented since 2013 (Reklev, 2016).

Concerning California, Borenstein et al. (2019) write "we find large ex ante uncertainty in business-as-usual emissions, and in the abatement that might result from non-market policies, compared to the market-based variation than could plausibly result from changes in allowance prices within a politically acceptable price range." They add "Comparable analysis seems likely to reach similar conclusions in most cap-and-trade markets for GHGs, consistent with outcomes to date in such markets."

\section{TRADABLE ENERGY-EFFICIENCY OBLIGATIONS}

Energy-efficiency obligations are a widespread policy tool consisting in a mandate imposed on energy suppliers to achieve a certain amount of energy savings, typically certified ex ante using standardized engineering calculations (Rosenow and Bayer, 2017; Aldrich \& Koerner, 2018). In some European countries, suppliers are allowed to meet a part of their obligation by purchasing 'energy-saving certificates', also called 'white certificates', from other firms which have generated more savings than their obligation. This policy tool thus falls in the category of tradable instruments. Tradable energyefficiency obligations have been first implemented in the United Kingdom in 2002, then in France in 2006 and more recently in Poland (Giraudet et al., 2021).

In France, the initially modest objective (over three years, 54 TWh cumulated and discounted over the investment lifetime) was gradually increased to 1600 TWh over the period 2018-2020, i.e. almost a thirtyfold increase, becoming the most ambitious in the world. On paper, the success is there: the French environment agency (Ademe, 2020, p.14) indicates that between 2011 and 2017, the system "allowed the installation or replacement of 580000 individual boilers and the replacement of collective 
heating systems for 735,000 flats; 300,000 wood heating appliances; 60,000 heat pumps, insulation of 78 million $\mathrm{m}^{2}, 2.1$ million windows and 5.9 million $\mathrm{A}+$ lamps".

However, there is little evidence on the proportion of these installations which would have occurred without the obligation (the 'additionality' issue). Indeed, there is a financial interest in generating energy-savings certificates even for investments which would have taken place without this system. This 'free riding', or more technically 'infra-marginal participation' does not necessarily generate an economic cost, but clearly reduces the effectiveness of the policy.

Unfortunately, there are no econometric studies on this issue of additionality; to quote Giraudet et al. (2012) "the lack of publicly available data [...] makes any empirical evaluation of white certificate obligations challenging."

Using a simulation model of the energy consumption by French buildings heating systems, Giraudet et al. (2018) conclude that only $9 \%$ of the energy savings financed by the energy-savings certificates system have been additional during the third commitment period (2015-2017). This should not come as a surprise since in this sector, which represents the majority of energy-savings certificates, the value of these certificates represents only around $5 \%$ of thermal renovation costs (Giraudet et al., 2020), less than other subsidies which can be cumulated with energy-efficiency certificates. Indeed, using multiple policy instruments reduces additionality (Fawcett et al., 2019). Whether additionality is higher for energy-savings certificates in other countries remains an open question, but unfortunately the same mechanism is likely to generate the same outcome.

The literature is scarce on the impact of the tradability of certificates itself. To my knowledge, the only formal analysis is due to Giraudet et al. (2021) who focus on imperfectly competitive, liberalised energy markets. They conclude that external compliance, i.e. the possibility for suppliers to targets customers of other suppliers may lower cost-efficiency: every supplier has an incentive to rely mostly on external compliance since internal compliance (targeting its own customers) decreases its energy sales. However, allowing the trading of obligation mitigates this adverse effect - but this benefit comes at the expense of consumers, who pay a higher energy price. 


\section{TRADABLE RENEWABLE ENERGY QUOTAS}

Under tradable renewable energy quotas, suppliers of electricity must achieve a certain percentage of production from renewable sources. If they exceed this level, they can sell 'green certificates' to companies that do not reach this percentage. A market for green certificates can thus be created. These systems are one of the main forms of support for renewable electricity in the United States, where many states have implemented them under the name of Renewable Portfolio Standards $(\text { RPS) })^{2}$. They also exist in South Korea and in some European countries and regions (at least in Sweden and Flanders; REN21 (2017, p. 205)). China is also considering using RPS instead of the current feed-in tariff.

In Quirion (2015), I summarise the economic research that compares these systems to other types of support in place: the feed-in tariff, which fixes in advance the amount received per unit of electricity sold, over a period of about 20 years; and the feed-in premium, which is added to the price of electricity sold on the market by producers. I conclude that renewable energy quotas have no significant advantage, but many shortcomings compared to other types of support.

First, they respond badly to uncertainty: if the cost of renewables is higher than expected or the cost of fossil fuels lower, it is justified to reduce the share of renewables, and vice versa. The quota, by fixing the share of renewables, does not allow this adjustment ${ }^{3}$. Conversely, in the case of a guaranteed feed-in tariff or premium, the share of renewables increases if their cost decreases, which is a step in the right direction (even if quantitatively, this adjustment is generally not optimal). Second, they generate a high differential rent: if a single target covers all renewables, the cheapest ones will generate a differential rent, since the price of green certificates will be set by the marginal energy. However, the cost differs widely between technologies; for example, large hydropower is generally much cheaper than biomass or marine energy and for the same technique, the location makes the cost vary widely (especially because of the different amount of wind or insulation and the distance from the electricity grid). In the case of a feed-in tariff or premium, it is easier to differentiate the level of support between market segments in order to reduce this differential rent.

\footnotetext{
${ }^{2}$ However, many RPS do not allow trading, so they are not tradable instruments as defined here.

${ }^{3}$ However, if a government wants to commit to a minimum share of renewable electricity, this policy tool ensures that it will comply with this target.
} 
Third, they can be affected by market power: electricity and gas markets are often dominated by a dominant operator (the historical monopoly) who can influence the price of green certificates to maximise its profit, resulting in a loss of efficiency. Thus, an operator in a seller's position on the green certificate market will have an interest in restricting its supply in order to raise the price of certificates (the classic problem of oligopoly) but also to raise the price of electricity, or even to exclude certain competitors ( "exclusionary manipulation", Cf. Misiolek and Elder, 1989).

Several empirical studies have attempted to estimate the effectiveness of various policies to support renewables around the world, using statistical approaches; see Carley et al (2017), García-Alvarez et al (2017) and the references therein. Unfortunately, it is very difficult to separate the 'pure' effect of these policies from the factors that influence both the development of renewables and the implementation of these same policies. Keep this caveat in mind, but most studies suggest that feedin tariffs (used in particular during the take-off of wind and photovoltaic in Denmark, Germany and China) have generally led to a greater development of renewables than renewable energy quotas. This is particularly the case of the econometric estimates carried out by García-Alvarez et al. (2017) on the development of wind power in Europe between 2000 and 2014. The authors conclude that feed-in tariffs have led to a statistically significant development of wind power in the countries and periods when they were in place, while the same result cannot be obtained for renewable energy quotas. Dong (2012) finds the same result, also for wind, over a panel of countries covering the period 2005-2009. With a more descriptive method, Alagappan et al. (2011) reach the same conclusion. One of the reasons put forward by these authors is the fact that feed-in tariffs reduce the risk for the investor, thus lowering the cost of capital compared to a situation where the source of remuneration is the sale of green certificates in a volatile market ${ }^{4}$. Another, more political advantage of this risk reduction is that it facilitates the involvement of investors who can hardly cover the risk themselves by diversifying their activities, as large companies do. Thus, SMEs, local authorities and citizens' associations can more easily invest in a renewable energy project if they know in advance the purchase price of the renewable electricity they plan to sell, rather than if these projects have to be remunerated through the sale of green certificates, at a price that is necessarily difficult to predict. The

\footnotetext{
${ }^{4}$ However, feed-in tariffs transfer the risk to the public budget or to the electricity consumer, which is especially problematic in developing countries.
} 
ongoing switch from feed-in-tariff to auctions and tenders in many countries has also been criticised for this reason (Grashof, 2019).

\section{ARE OTHER POLICIES MORE EFFECTIVE?}

Taking stock of the effectiveness of all climate policies is a huge task, which I can only outline here. First of all, it is clear that tradable instruments do not have a monopoly on ineffectiveness. There are many cases of taxes that are ineffective because they are set at a very low rate and riddled with exemptions. Also, many subsidies fund mostly infra-marginal investments, i.e. investments that would have taken place without them. Moreover, many regulations are little respected, the one on nitrogen oxide emissions from cars marketed in Europe being the most publicised case since the dieselgate, but by no means an exception.

However, unlike tradable instruments, it is easy to cite cases of subsidies, taxes and regulations that have proven their effectiveness. For subsidies, the most obvious case is undoubtedly the feed-in tariffs for electricity from renewable sources. In Denmark and Germany, and subsequently in many countries and regions of the world, these systems have enabled wind and solar photovoltaic to move from being a niche market (presented as being of interest, at best, only in areas not connected to a large electricity grid) to being a key technology for producing $\mathrm{CO}_{2}$-free electricity (Nicolini and Tavoni, 2017).

As regards regulations, one may cite those on the efficiency of electrical appliances, which today cover the main electricity consumption items, from refrigerators to washing machines, and which have made it possible to reduce consumption massively; or the thermal regulations on new buildings, introduced since 1975 in France and gradually tightened, which have made it possible to halve energy consumption for heating between dwellings built before 1975 and those built since 2000 (Lepoittevin, 2017, p. 52).

Finally, taxes on $\mathrm{CO}_{2}$ emissions have proven effective in Sweden (Andersson, 2019) and Great Britain $^{5}$. In Great Britain, a system called the Carbon Price Support has been in place since 2013. It is a tax on $\mathrm{CO}_{2}$ emissions, equal to $£ 18 / \mathrm{tCO}_{2}$ since 2016. This tax is added to the market price of

\footnotetext{
${ }^{5} \mathrm{~A}$ caveat is that in most cases, taxes have mostly impacted operational, rather than investment decisions (Lilliestam et al., 2021).
} 
European allowances, the sum of the two reaching $£ 32 / \mathrm{t} \mathrm{CO}_{2}$ on average over 2018. $\mathrm{CO}_{2}$ emissions from power stations have decreased by 55\% since 2012 (UK, 2018), a trend not found in other European countries. Very few public policies have such a track record in the fight against climate change, certainly not those that fall under what I call here 'tradable instruments'.

Why are tradable instruments so rarely effective, compared to others? A possible explanation may be that with non-tradable instruments, even if some regulated firms face a target that they can satisfy without any effort, others may face tougher targets, hence have to implement mitigation measures. With tradable instrument, lenient targets allow concerned firms to sell tradable allowances or certificates, making overallocation the general case. However, more research is needed to address this question.

\section{CONCLUSION}

At the end of this brief overview, the assessment of the implementation of tradable instruments in the fight against greenhouse gas emissions is not very positive. Emission trading has suffered from overallocation which has undermined its effectiveness; energy-efficiency obligations seem to have mostly co-financed investments that would have taken place anyway; tradable renewable energy quotas suffer from several shortcomings compared to alternative support systems, i.e., feed-in tariffs and premiums.

Who should be blamed for this relative failure? Of course, industrial lobbies have contributed to the inefficiency of these tradable instruments, for example by making emission ceilings less ambitious, but this is also the case for regulations (as we saw with dieselgate) and subsidies.

A more specific reason seems to be that public authorities (at least in Europe) have often based their action and regulations on a superficial reading of the work of researchers, retaining only the theoretical argument of the superiority of tradable instruments over regulations - an argument which is certainly found in environmental economics textbooks, but which cannot summarise the mass of work devoted to these tradable instruments. For instance, most work on the reform of the European emission trading system concludes that a floor price for allowances would improve the EU ETS, but this proposal has not been accepted by the European Union. The ideological nature of the European Commission's argument is in this respect striking in its free-market fundamentalism (Branger et al., 2015). 
How can things be improved? Without having the naivety to think that public policies are systematically taken in favour of the general interest, it seems to me that two developments would favour a better informed debate.

The first change would consist in writing systematic syntheses of academic work in support of public policies, as the IPCC does on climate or the IPBES on biodiversity, but on much more specific themes, those that are the subject of the public policies under discussion. On subjects such as the reform of the European Union Emission Trading System, or the choice of a mode of support for renewable energies, such syntheses could have clarified the arguments in favour of the different options. Admittedly, concerning other public policies, scientific production was extremely limited at the time of decision-making; this was the case for energy-efficiency obligations when they were introduced. Nevertheless, as these policies are generally reformed at regular intervals and often generate research as soon as they are introduced, a systematic synthesis is generally possible to inform these reforms.

A second desirable development is to encourage the production of data that can be used by researchers and to make them available. In this respect, although notable progress has been made, access to data produced by public authorities remains highly heterogeneous across providers. Moreover, public policies rarely include provisions that would facilitate their ex-post evaluation by researchers, even though these would sometimes be very inexpensive.

Such changes would lead to a greater 'economisation' of the environment in the sense that economic research would be taken into account to a greater extent, but it would not necessarily entail more and potentially even less - role for markets, judging by the disappointing track record of market instruments in the fight against climate change so far.

\section{DATA AVAILABILITY STATEMENT}

Data sharing not applicable - no new data generated 


\section{REFERENCES}

Ademe (2020). Evaluation du dispositif des certificats d'économie d'énergie - Rapport synthétique, Ademe.

Alagappan, L., Orans, R., \& Woo, C. K. (2011). What drives renewable energy development?. Energy policy, 39(9), 5099-5104.

Aldrich, E. L., \& Koerner, C. L. (2018). White certificate trading: A dying concept or just making its debut? Part II: Challenges to trading white certificates. The Electricity Journal, 31(4), 41-47.

Andersson, J. J. (2019). Carbon Taxes and CO 2 Emissions: Sweden as a Case Study. American Economic Journal: Economic Policy, 11(4), 1-30.

Bailey, I. (2010). The EU emissions trading scheme. Wiley Interdisciplinary Reviews: Climate Change, 1(1), 144-153.

Borenstein, S., Bushnell, J., Wolak, F. A., \& Zaragoza-Watkins, M. (2019). Expecting the unexpected: Emissions uncertainty and environmental market design. American Economic Review, 109(11), 395377.

Branger, F., Lecuyer, O., \& Quirion, P. (2015). The European Union Emissions Trading Scheme: should we throw the flagship out with the bathwater?. Wiley Interdisciplinary Reviews: Climate Change, 6(1), 9-16.

Burtraw, D., \& Keyes, A. (2018). Recognizing gravity as a strong force in atmosphere emissions markets. Agricultural and Resource Economics Review, 47(2), 201-219.Carley, S., Baldwin, E., MacLean, L. M., \& Brass, J. N. (2017). Global expansion of renewable energy generation: an analysis of policy instruments. Environmental and resource economics, 68(2), 397-440.

Crocker, T. D. (1966). The structuring of atmospheric pollution control systems. In: Wolozin H (ed.), The Economics of Air Pollution, A Symposium, pp. 61-86.

Dales, J. H. (1968). Land, water, and ownership. The Canadian Journal of Economics/Revue canadienne d'Economique, 1(4), 791-804.

Dong, C. G. (2012). Feed-in tariff vs. renewable portfolio standard: An empirical test of their relative effectiveness in promoting wind capacity development. Energy Policy, 42, 476-485.

Buchner, B., \& Ellerman, E. D. (2006). Over-allocation or abatement? A preliminary analysis of the EU ETS based on the 2005-06 emissions data. Environmental and Resource Economics, 2008, 41(2), 267-287. 
Fawcett, T., Rosenow, J., \& Bertoldi, P. (2019). Energy efficiency obligation schemes: their future in the EU. Energy Efficiency, 12(1), 57-71.

Flachsland, C., Pahle, M., Burtraw, D., Edenhofer, O., Elkerbout, M., Fischer, C., ... \& Zetterberg, L. (2020). How to avoid history repeating itself: the case for an EU Emissions Trading System (EU ETS) price floor revisited. Climate Policy, 20(1), 133-142.

Fuss, S., Flachsland, C., Koch, N., Kornek, U., Knopf, B., \& Edenhofer, O. (2018). A framework for assessing the performance of cap-and-trade systems: insights from the European Union emissions trading system. Review of Environmental Economics and Policy, 12(2), 220-241.

García-Álvarez, M. T., Cabeza-García, L., \& Soares, I. (2017). Analysis of the promotion of onshore wind energy in the EU: Feed-in tariff or renewable portfolio standard?. Renewable energy, 111, 256264.

Giraudet, L. G., Bodineau, L., \& Finon, D. (2012). The costs and benefits of white certificates schemes. Energy efficiency, 5(2), 179-199.

Giraudet, L.-G., Bourgeois, C., Quirion, P. \& Glotin, D. (2018). Evaluation prospective des politiques de réduction de la demande d'énergie pour le chauffage résidentiel. Rapport pour Ademe, MTES et ATEE, CIRED

Giraudet, L.-G., Bourgeois, C. \& Quirion, P. (2020) Efficacité économique et effets distributifs de longterme des politiques de rénovation énergétique des logements. Economie et Prévision, 2020/1 (N²17), 43-63

Giraudet, L. G., Glachant, M., \& Nicolaï, J. P. (2020). Selling and Saving Energy: Energy Efficiency Obligations in Liberalized Energy Markets. The Energy Journal, 41 (Special Issue).

Grashof, K. (2019). Are auctions likely to deter community wind projects? And would this be problematic?. Energy Policy, 125, 20-32.

Laing, T., Sato, M., Grubb, M., \& Comberti, C. (2014). The effects and side-effects of the EU emissions trading scheme. Wiley Interdisciplinary Reviews: Climate Change, 5(4), 509-519. Lepoittevin, D. (2017). Analyse des résidences principales et de leurs occupants, au travers de l'étiquette énergie conventionnelle du diagnostic de performance énergétique (DPE). Thema Analyse, Service de l'observation et des statistiques, ministère de l'écologie, mars. 
Lilliestam, J., Patt, A., \& Bersalli, G. (2021). The effect of carbon pricing on technological change for full energy decarbonization: A review of empirical ex-post evidence. Wiley Interdisciplinary Reviews: Climate Change, 12(1), e681.

Misiolek, W. S., \& Elder, H. W. (1989). Exclusionary manipulation of markets for pollution rights. Journal of Environmental Economics and Management, 16(2), 156-166.

Moledina, A. A., Coggins, J. S., Polasky, S., \& Costello, C. (2003). Dynamic environmental policy with strategic firms: prices versus quantities. Journal of Environmental Economics and Management, 45(2), 356-376.

Montgomery, W. D. (1972). Markets in licenses and efficient pollution control programs. Journal of Economic Theory, 5(3), 395-418.

Narassimhan, E., Gallagher, K. S., Koester, S., \& Alejo, J. R. (2018). Carbon pricing in practice: A review of existing emissions trading systems. Climate Policy, 18(8), 967-991.

Newell, R. G., \& Pizer, W. A. (2008). Indexed regulation. Journal of Environmental Economics and Management, 56(3), 221-233.

Nicolini, M., \& Tavoni, M. (2017). Are renewable energy subsidies effective? Evidence from Europe. Renewable and Sustainable Energy Reviews, 74, 412-423.

OECD, 2020, Policy Instruments for the Environment (PINE) Database, http://oe.cd/pine, accessed on [14/09/2020].

Park, H., \& Lee, M. (2020). Factors determining firms' trading decision in the Korea ETS market. Environmental Economics and Policy Studies, 1-24.

Perino, G. (2018). New EU ETS Phase 4 rules temporarily puncture waterbed. Nature Climate Change, 8(4), 262-264.

Pizer, W. A. (1999). The optimal choice of climate change policy in the presence of uncertainty. Resource and Energy Economics, 21(3-4), 255-287.

Postic, S., \& Fettet, M. (2020). Global Carbon Account in 2020. I4CE, Paris, May. https://www.i4ce.org/download/global-carbon-account-in-2020/ Quirion, P. (2005). Does uncertainty justify intensity emission caps?. Resource and Energy Economics, 27(4), 343-353.

Quirion, P. (2015). Quels soutiens aux énergies renouvelables électriques?. Revue française d'économie, 30(4), 105-140. 
Reklev, S. (2016). Allowance surplus in China's pilot markets to grow as slowdown hits power, manufacturing sectors. Carbon Pulse, January 19, http://carbon-pulse.com/14356/ REN21. Renewables 2017 Global Status Report. Paris, 2017: REN21 Secretariat. ISBN 978-39818107-6-9

Rosenow, J., \& Bayer, E. (2017). Costs and benefits of Energy Efficiency Obligations: A review of European programmes. Energy Policy, 107, 53-62.

Smessaert, J., Missemer, A., \& Levrel, H. (2020). The commodification of nature, a review in social sciences. Ecological Economics, 172, 106624.

Smith, S., \& Swierzbinski, J. (2007). Assessing the performance of the UK Emissions Trading Scheme. Environmental and Resource Economics, 37(1), 131-158.

UK. Provisional UK greenhouse gas emissions national statistics 2017, 2018.

https://www.gov.uk/government/collections/provisional-uk-greenhouse-gas-emissions-national$\underline{\text { statistics }}$

Weitzman, M. L. (1974). Prices vs. quantities. The Review of Economic Studies, 41(4), 477-491. 